\title{
Katarzyna Michalewicz*
}

Instytut Historyczny, Uniwersytet Wrocławski

\section{Sytuacja gospodarcza w Japonii na łamach wybranych polskich czasopism z lat 30. XX wieku: kwartalnika „Wschód”, miesięcznika „Z Daleka i Bliska” oraz tygodnika "Anteny”}

\begin{abstract}
Streszczenie: W latach 30. XX wieku zainteresowanie Polaków Krajem Kwitnącej Wiśni było duże. Świadczą o tym liczne notatki, które ukazywały się zarówno w czasopismach o charakterze naukowym, popularnonaukowym, krajoznawczym, jak i informacyjnym. Jednak o ile w latach 20. XX wieku obywateli II Rzeczpospolitej interesowały przede wszystkim zagadnienia związane z kulturą Japonii, to po wybuchu konfliktu na Dalekim Wschodzie i aneksji Mandżurii przez państwo Hirohito w prasie zaczęła dominować tematyka związana z gospodarką, polityką i sytuacją wewnętrzną w Kraju Wschodzącego Słońca.

Jednym z czasopism, które najczęściej wspominały na swoich łamach o Japonii, było orientalne czasopismo popularnonaukowe „Wschód”, (1930-1939), krajoznawcze: „Z Daleka i Bliska” (1933-1939), a także program radiofoniczny: „Antena” (1934-1939).
\end{abstract}

\section{Zainteresowanie Polaków Japonią}

Geneza relacji polsko-japońskich oraz zainteresowania Polaków tym dalekowschodnim państwem jest bardzo długa. Według autorów „Wscho-

* katarzyna.michalewicz@poczta.onet.pl, Michalewicz, K. (2019). Sytuacja gospodarcza w Japonii na łamach wybranych polskich czasopism z lat $30 \mathrm{XX}$ wieku: kwartalnika „Wschód”, miesięcznika „Z Daleka i Bliska” oraz tygodnika „Anteny”. Annales Collegii Nobilium Opolienses, 8, s. 117-129. 
du" pierwsze polskie wzmianki na temat odległego kraju, pojawiły się już w późnym średniowieczu. Dowodem miała być wydawana w Krakowie w 1585 roku książka o Japonii ${ }^{1}$. Późniejsze polskie piśmiennictwo również wiele miejsca poświęcało zagadnieniom związanym z państwem samurajów. Na łamach „Wschodu” w latach 1930-1931 ukazał się nawet cykl artykułów autorstwa Kamila Seyfrieda, poświęconych polskiej bibliografii o Kraju Kwitnącej Wiśni ${ }^{2}$. Autor podał w nim listę polskich książek poświęconych Japonii, która liczyła sobie kilkaset tytułów.

Z prasy jednoznacznie wynika, że Polacy mieli sentyment do Japonii $\mathrm{z}$ kilku powodów. Uważali oni bowiem ten kraj za naturalnego sojusznika podczas wojny rosyjsko-japońskiej. Wiedza o tych wydarzeniach miała być powszechnie znana $\mathrm{w}$ społeczeństwie i na bieżąco śledzona. Jan Niwiński wspomina, że już jako mali chłopcy z zaciekawieniem nadsłuchiwali kolejnych wiadomości o wydarzeniach na froncie i często sami bawili się w strategów ${ }^{3}$.

Polacy pamiętali także o tym, że Japończycy szczególną opieką otoczyli wszystkie polskie sieroty ewakuowane z Syberii. Była to specjalna akcja ratowania polskich dzieci zorganizowanej przez Annę Bielkiewicz i Józefa Jakóbkiewicza w latach 1919-1922. Bardzo dużo wsparcia i serca tym działaniom okazał zarówno rząd japoński, z cesarzową Sadako na czele, jak i zwykli mieszkańcy Kraju Kwitnącej Wiśni. Wzmianka o tym wydarzeniach pojawiła się nawet $\mathrm{w}$ m.in. czasopiśmie filozoficzno-ezoterycznym „Lotos”.

Niestety wiedza przeciętnego obywatela II Rzeczpospolitej na temat Kraju Kwitnącej Wiśni nie była imponująca i często dosyć powierzchowna. „Antena” ubolewała nad tym, że przeciętny polski czytelnik patrzy na Japonię tylko poprzez pryzmat popularnych przekładów Kwiatkowskiego, albo w najlepszym przypadku poprzez operę Butterfly Puccinniego. Jednak przynajmniej ta opera miała wzbudzić większe zainteresowanie Krajem Kwitnącej Wiśni w Polsce 5 .

1 „Od redakcji”, Kwartalnik „Wschód”, R. 1, nr 1, lipiec 1930 r., s. 3.

2 Materjały do bibljografji japońskiej (I), K. Seyfried, Kwartalnik „Wschód”, R. 1, nr 2, grudzień 1930 r., s. 10.

3 Generał Nogi, J. Niwiński, R. 3, nr 5-6, styczeń 1932 r., s. 4-5.

4 W. Loga, Mobilizacja ducha narodu japońskiego (Szyntoizm - religia narodowa Japończyków.), „Lotos”, R. 6, nr 2, Wisła, Sląsk Cieszyński, luty 1939, s. 228.

5 W. Burkath, Radjo w Krainie Kwitnącej Wiśni, „Antena”, R. 2, nr 43, 27 października 1935, s. 13. 
$\mathrm{Z}$ drugiej strony polski czytelnik $\mathrm{z}$ lat 30 . XX wieku był na bieżąco informowany o wydarzeniach $\mathrm{z}$ wschodniej Azji, co też przyczyniało się do wzrostu zainteresowania tematyką dalekowschodnią wśród Polaków, a także wzrostem publikacji na ten temat. Wspomina o tym jedna $\mathrm{z}$ recenzji książki popularnonaukowej, zamieszczona na łamach „Z Daleka i Bliska”. „Jakkolwiek codzienne prawie dochodzą nas wieści z Dalekiego Wschodu o coraz to nowych incydentach na granicach Mandżurii, szerszy ogół mało, albo nic nie wie o tym olbrzymim kraju, pozostającym pod »opieką« małej Japonii. »Mandżuria« Aleksandrowicza ma tę zaletę, że napisana jest łatwo, popularnie i obejmuje wszystkie najważniejsze zagadnienia, jakie nasuwają się przy ogólnym opisie kraju, a więc: położenie geograficzne, historia, ludność, bogactwa naturalne, życie gospodarcze, przemysł, handel, górnictwo, komunikacja. Bardziej szczegółowo omówił autor dzieje kolonii polskiej i możliwości handlowe pomiędzy Polską a Mandżurią" C. Czytelnicy tego tytułu mogli także zapoznać się z recenzją książki Antoniego Zischka Japonia. Autor opinii zachwalał, że jest ona jedną z najlepszych monografii z zakresu geografii gospodarczej i politycznej. Podkreślił również, że posiada wiele zajmującego i źródłowego materiału i powinna być dopuszczona do użytku szkolnego ${ }^{7}$.

Szczególną rolę w propagowaniu wiedzy o Japonii wśród swoich rodaków odgrywali również ...esperantyści. Działo się tak, ponieważ to właśnie ten język umożliwiał przełamanie bariery językowej i nawiązanie bliższych relacji Polaków z Japończykami, a także wymiany kulturowej. Jednym z nich był Karol Klein - miłośnik esperanto, który korespondował przez wiele lat w tym języku z mieszkańcami Kraju Kwitnącej Wiśni: studentem wyższej szkoły handlowej w Osaka - Dancuji Hiroshi, licealistką Nobuko Aota, studentką uniwersytetu Tokijskiego - Yuki Isobe. Autor wspomina o tym, że jeden z jego przyjaciół na bieżąco opisywał swoje osobiste przeżycia z okresu, kiedy jego miasto nawiedziło trzęsienie ziemi w 1923 roku. Jak podkreśla Karol Klein, dowiedział się wtedy o tych wydarzeniach znacznie więcej niż z prasy polskiej, która szeroko rozpisywała się na ten temat. Ze swoimi znajomymi wymieniał się: czasopismami, fotografiami, książkami, a także przedmiotami wyrobu artystycznego

6 W.W. A. Aleksandrowicz, Mandżuria, jej przeszłość, teraźniejszość, kraj i ludzie, „Z Daleka i Bliska”, R. 7, nr 62-63, kwiecień-maj 1939, s. 142.

7 A. Zischka, Japonia, „Z Daleka i Bliska”, R. 5, nr X, Lwów, X 1937, s. 137. 
i ludowego. Za jego namową do tej wymiany dołączyły także uczennicy z jednej szkół lwowskich ${ }^{8}$.

Warto tutaj zaznaczyć, że język esperanto był bardzo popularny w Japonii. Dowodem na to było owacyjne przyjęcie przez mieszkańców Kraju Kwitnącej Wiśni esperantysty Józef Scherera, który zajmował się popularyzacją tego języka ${ }^{9}$. Ponadto $w$ tym czasie esperanto stało się językiem elit naukowych. Świadczył o tym fakt, że Akademia Medyczna w Tokio przyjęła esperanto jako oficjalny język naukowy, a w Kraju Kwitnącej Wiśni powstawały prace doktorskie w esperanckim, a nawet istniała możliwość składania egzaminów u niektórych profesorów w tym narzeczu. Ponadto japońskie obserwatorium meteorologiczne w Tateno wydawało stale w latach 30. XX wieku biuletyn w języku esperanto ${ }^{10}$.

\section{Japońskie miasta}

Kraj Kwitnącej Wiśni w polskich czasopismach jawił się jako prężnie rozwijające się państwo, gdzie nowoczesność łączy się z tradycją. Numer „Z Daleka i Bliska” z 1936 roku wyliczał, że Japonia posiadała aż 34 wielkich miast, w tym cztery miasta milionowe, dwa połmilionowe, 28 stutysięcznych, a także 53 miast pięćdziesięciotysięcznych. Wśród największych metropolii wymieniała: Tokio (8 875000 mieszkańców), Osaka (2 990 000), Nagoja (1 830 000), Kioto (1 810 000), Kobe (912 000) i Jokohama (704 000). Czasopismo podkreśliło przy tym, że siódme co do wielkości japońskie miasto liczy sobie ponad 300000 mieszkańców, czyli mniej więcej tyle co Lwów ${ }^{11}$.

Prasa podkreślała również, że obecna stolica Japonii, zaraz po Nowym Jorku i Londynie, ma być trzecim największym miastem na świecie. Dodawała, że w 1932 roku powstało tzw. Wielkie Tokio, które liczyło sobie 5408000 mieszkańców. Taki wzrost miało jednak zawdzięczać nie

8 K. Klein, Jak to było w Japonii, „Z Daleka i Bliska”, R. 4, nr 31, Lwów, marzec 1936, s. 88.

9 Tamże, s. 82-83.

10 Japońskie obserwatorium meteorologiczne, „Z Daleka i Bliska”, R. 3, nr 27, Lwów, listopad 1935, s. 268.

11 Zaludnienie Japonii w 1935, „Z Daleka i Bliska”, R. 4, nr 32, Lwów, kwiecień 1936, s. 126. 
przyrostowi naturalnemu bądź imigracji, ale przyłączeniu do siebie 82 przedmieść i osad ${ }^{12}$.

„Z Daleka i Bliska” informowało również czytelnika o tym, że wśród powyżej wymienionych metropolii najchętniej odwiedzanymi zarówno przez turystów, jak i biznesmenów są: Tokio, Osaka, Kobe, Yokohama. Podkreślało jednak przy tym, że choć zachwycają one rozmiarem, amerykanizacją, liczbą przedsiębiorstw przemysłowych, handlowych i finansowych na światową skalą, to rozczarowują szablonowością i mechanizacją. Odkrywają one swoje prawdziwe piękno dopiero wtedy, gdy wyjdzie się poza obręb ich centrów. Ponieważ tylko tam można odnaleźć „japońską duszę".

Na tle metropolii wyjątkiem jest jedynie Tokio, które z powodu utraty miana stolicy uchroniło się przed europeizacją i modernizacją. Według autora jest ono nadal: kwintesencją dawnej japońszczyzny, najlepszym ucieleśnieniem japońskiego ducha, japońskiej tradycji i japońskiego piękna, a także odzwierciedleniem marzeń i wyobrażeniom o Japonii. Dziennikarz jednak podkreśla, że ,japońska dusza” jest także ukryta w mniejszych miastach oraz na prowincji, gdzie życie i obyczaje, pomimo postępu technologicznego, nie zmieniły się zbytnio ${ }^{13}$.

\section{Kryzys i militaryzacja w Japonii}

$\mathrm{Na}$ łamach polskiej prasy $\mathrm{z}$ lat 30. XX wieku wyłaniał się jednak także mniej korzystny obraz państwa Hirohito. Polscy czytelnicy mogli dowiedzieć się z niej także o kryzysie gospodarczym i militaryzacji w Japonii. Szczególnie dużo na ten temat rozpisywał „Wschód”, który poświęcił obu tematykom kilka obszernych artykułów.

Według autorów kwartalnika kryzys osiągnął „zastraszające rozmiary” i objawiał się przede wszystkim wciąż rosnącym bezrobociem oraz upadkiem wielu drobnych firm. Wśród przyczyn takiego stanu rzeczy w Kraju Kwitnącej Wiśni wymieniali zarówno czynniki zewnętrzne - bojkot towarów japońskich przez Chiny, jak i wewnętrzne - zniesienie embarga na

12 J. St. P., Tokio - trzecim miastem świata, „Z Daleka i Bliska”, R. 1, nr 4, Lwów, wrzesień 1933, s. 116.

13 R. Fajans, Kioto, „Antena”, R. 5, nr 36, 4 wrzesień, s. 7. 
złoto przez gabinet Minseito ${ }^{14}$. Szczególnym zagrożeniem dla gospodarki japońskiej miał być wspomniany bojkot, ponieważ handel Cesarstwa z Republiką stanowił 1/3 ogólnego handlu zagranicznego Nipponu, a eksport do Chin - 1/4 część ogólnego eksportu. Tytuł podkreślał, że to właśnie Japonia, zaraz po Stanach Zjednoczonych, była największym eksporterem na rynku chińskim ${ }^{15}$.

Nie były to jedyne bolączki wyspiarskiego kraju. W artykułach poświęconych sytuacji wewnętrznej Japonii wielokrotnie przewija się wątek przeludnienia. Z „Daleka i Bliska” przytoczył spis z 1 października 1935 roku, według którego Japonię zamieszkiwało 97625000 osób. Wyspy japońskie liczyły sobie 69251000 osób, Korea 22899 000, Formoza 5213 000, japoński Sachalin 332000 mieszkańców. Mężczyzna miało być o 787000 więcej niż kobiet ${ }^{16}$. Natomiast „Wschód” dodawał przy tym, że Kraj Wschodzącego Słońca, bez okupowanych terenów, zamieszkiwało około 65 milionów osób, a przyrost ludności wynosił około miliona rocznie ${ }^{17}$.

Inną przeszkodą utrudniającą rozwój państwa Hirohito był brak surowców m.in. złóż naturalnych. Ponadto Japonia jako kraj skalisty posiadała tylko $15 \%$ powierzchni zdatnych do uprawy ${ }^{18}$.

Ponadto prasa wspominała o tym, że Japonia była w przeszłości i obecnie wciąż jest wielokrotnie nawiedzana przez liczne klęski żywiołowe, takie jak wybuchy wulkanów i trzęsienia ziemi. Dowiadujemy się z notatek prasowych, że aktywnymi wulkanami, oprócz góry Fuji, są: Asam-yama, Bandaisan, Sakura-jima, Shiane-san. Co więcej, stanowią one także większe zagrożenie dla kraju niż najsłynniejsza japońska góra. Natomiast trzęsienia ziemi miały stać się dla Japończyków zjawiskiem niemal codziennym. Jedno z największych nawiedziło Japonię w 1923 roku. Śmierć poniosło wtedy aż 150 tysięcy osób ${ }^{19}$.

14 Elementy wewnętrznej sytuacji w Japonji, J.Z., Kwartalnik „Wschód”, R. 3, nr 7-8, sierpień-wrzesień 1932 r., s. 38.

15 Konflikt Zbrojny Chin i Japonji, W. Bronowski, Kwartalnik „Wschód”, R. 3, nr 7-8, sierpień-wrzesień 1932 r., s. 18-19.

16 Zaludnienie Japonii w 1935, „Z Daleka i Bliska”, R.4, nr 32, Lwów, kwiecień 1936, s. 126.

17 Konflikt Zbrojny Chin i Japonji, W. Bronowski, Kwartalnik „Wschód”, R. 3, nr 7-8, sierpień-wrzesień 1932 r., s. 22.

18 Konflikt Zbrojny Chin i Japonji, W. Bronowski, Kwartalnik „Wschód”, R. 3, nr 7-8 , sierpień-wrzesien 1932 r., s.22.

19 W. Zinkiewicz, Z Krainy kwitnącej wiśni, wulkanów i trzęsień ziemi, „Z Daleka i Bliska”, R. 3, nr 26, Lwów, październik 1935, s. 228. 
„Z Daleka i Bliska” przestrzegało, że taka sytuacja może wkrótce doprowadzić do eskalacji konfliktu w tym regionie, a państwem, które najprawdopodobniej szczególnie ucierpi, będzie Rosja. „Stumilijonowa ludność silnie się rozrastającego narodu japońskiego nie może się już dłużej dusić na nierodzajnych wyspach, pozbawionych bogactw mineralnych i większości niezbędnych surowców. Japonia więc idąc po najmniejszej linji oporu, względnie mając największe interesy w pobliżu t.j. Mongolji i Syberji wschodniej, po zagarnięciu Mańdzurji, tam zwróci swe siły i całą energję. Ten pochód jest nieunikniona koniecznością, wcześniej czy później Japonja ów obszar zagarnie, czy na mocy układów pokojowych, czy siłą zbrojną" 20 .

Wcześniej autor wspominał jednak o ekspansji politycznej Japonii i pokrótce opisał jej ekspansję polityczną. Zaznaczył przy tym, że Kraj Wschodzącego Słońca ma co około dziesięć lat dokonywać kolejnych podbojów, a jej głównym celem stanie się wybrzeże pacyficzne Azji, a przede wszystkim Chiny, które z kolei z powodu złej sytuacji wewnętrznej są szczególnie narażone na agresywne działania swojego wyspiarskiego sąsiada. Na potwierdzenie swojej tezy przytacza takie wydarzenia jak: aneksja Mandżurii i koronacja cesarza mandżurskiego - $\mathrm{Pu}$ Yi. Te poczynania według niego stały się kolejnym etapem w zagarnięciu tej prowincji chińskiej liczącej 31 milionów mieszkańców ${ }^{21}$.

Podobne zdanie na temat przyczyn japońskiej ekspansji miał kwartalnik „Wschód”. Wskazywał jednak jeszcze na dodatkowe czynniki. Na jego łamach Kraj Kwitnącej Wiśni jawił się jako lokalna potęga, która, w przeciwieństwie do innych krajów Azji, osiągnęła pozycję równorzędnego partnera dla europejskich mocarstw. Autorzy kwartalnika podkreślali przy tym, że w ubiegłym stuleciu Kraj Wschodzącego Słońca uniknął losu m.in. Państwa Środka, dzięki sprawnej modernizacji. Dlatego przyrównywali Japonię do zdolnego ucznia, który potrafił czerpać wiedzę od Europejczyków, szczególnie w zakresie wojskowości.

Jednak, jak zaznaczali, państwo, pomimo silnej pozycji, na Dalekim Wschodzie nie wystrzegało się błędów, jakim było szerzenie w społeczeństwie idei imperialistycznych oraz chęć poszerzenia swoich granic naj-

20 J. Ślebodziński, Chmury nad Azją zwiastują groźną burzę, „Z Daleka i Bliska”, R. 4, nr 30, Lwów, luty 1936, s. 53-54.

21 J. Haliczer, Wojna czy pokój na Dalekim Wschodzie, „Z Daleka i Bliska”, R. 2, nr 11, Lwów, kwiecień 1934, s. 83-85. 
pierw kosztem Chin, a później innych państw azjatyckich ${ }^{22}$. Podkreślili przy tym, że nie była to jedynie decyzja władz, ale wpływ na to miało również Japońskie społeczeństwo, które poparło próby aneksji i późniejsze zajęcie Mandżurii. Te nastroje wyjaśniali tym, że zwykli obywateli, upatrywali w przejęciu tego regionu szansy utrzymania silnej pozycji na arenie międzynarodowej własnej ojczyzny, a także uchronienia jej interesów ${ }^{23}$.

\section{Japońskie rolnictwo i handel}

Szczególnie dużo miejsca japońskiej gospodarce poświęcało „Z Daleka i Bliska”. Z artykułów na ten temat czytelnik dowiadywał się, że ważną rolę odgrywało tutaj rolnictwo, a szczególnie uprawa ryżu. Prasa podkreślała, że jest on najważniejszą rośliną uprawną w Państwie Wschodzącego Słońca, natomiast kraj ten zajmuje trzecie miejsce w światowej produkcji tego surowca. Japońscy rolnicy muszą jednak włożyć wiele pracy i trudów, aby zebrać plon ryżowy. Wszystko bowiem zależy od opadów, a samo pole musi zostać nawożone związkami azotu, wapnia i fosforu. Dlatego w Kraju Kwitnącej Wiśni aż 50\% gruntów ornych zajmują właśnie pola ryżowe ${ }^{24}$.

Jak zaznaczali autorzy, nie jest to jednak jedynie zajęcie rolników. Często zajmują się oni także hodowlą morw i jedwabników. Tym zajęciem, które niejednokrotnie stanowi ich jedyne źródło utrzymania, trudni się aż 2 miliony chłopskich rodzin. Pomimo jednak wysiłku, jaki trzeba włożyć w tę pracę, tytuł podkreślał, że Japończycy oddają się tej pracy z zamiłowaniem i stale dążą do powiększenia i udoskonalenia produkcji. Natomiast jedwab jest najważniejszym towarem eksportowym i zajmuje 50\% wywozu, a sama Japonia jest pierwszym państwem w produkcji tej tkaniny na świecie ${ }^{25}$.

Z prasy dowiadujemy się również, że Japończycy z kolei importowali liczne towary zarówno z Europy, jak i Australii. „Z Daleka i Bliska” wspo-

22 Zarys stosunków rosyjsko-japońskich, W. Pelc, Kwartalnik „Wschód”, R. 6, nr 17-18, styczeń-sierpień 1935 r., s. 78-79.

23 Konflikt Zbrojny Chin i Japonji, W. Bronowski, Kwartalnik „Wschód”, R. 3, nr 7-8, sierpień-wrzesień 1932 r., s. 22.

24 W. Zinkiewicz, Z Krainy kwitnącej wiśni, wulkanów i trzęsień ziemi, „Z Daleka i Bliska”, R. 3, nr 26, Lwów, październik 1935, s. 225.

25 Tamże, s. 229. 
minał, że: „Import towarów japońskich do Bułgarii wzrósł z 770000 lewa w r. 1934 do 2090000 lewa w r. 1937. Na import japoński składają się głównie towary szklane, porcelana, zabawki, żarówki i wyroby tekstylne. Import japoński wzrasta kosztem Czechosłowacji i Niemiec. Obecnie prowadzone są między Bułgarią i Japonią nowe rokowania celem rozszerzenia dotychczasowych obrotów handlowych. Japonia zakupuje w Bułgarii zboże i inne produkty rolnictwa" ${ }^{26}$. Bułgaria nie była jednak jedynym krajem na Starym Kontynencie, który dostarczał Japonii materiałów w latach 30. ubiegłego wieku. Z prasy dowiadujemy się również o polskich towarach, które dotarły do kraju Kwitnącej Wiśni. „Niedawno wysłano z Wileńszczyzny pierwszą partię włókna lnianego do Japonii, poczem firma eksportowa zyskała nowe zamówienie z Japonii. Tak więc krąg odbiorców polskiego włókna lnianego stale wzrasta"27. Natomiast cztery lata wcześniej z Gdyni odszedł pierwszy w historii handlu polskiego ładunek amoniaku dla Japonii ${ }^{28}$.

Szczególną rolę w japońskim imporcie odgrywała także wełna, którą Kraj Kwitnącej Wiśni odkupywał od Australii i Nowej Zelandii. Jak jednak podaje „Z Daleka i Bliska”, aby temu zapobiec, od kilku lat rząd japoński planuje zwiększyć liczbę owiec, która obecnie wynosi kilkadziesiąt tysięcy sztuk. W ciągu dekady ich liczba ma wzrosnąć do trzech milionów, a w ciągu 20 lat do 7 milionów. W tym celu program rządowy przewiduje udzielanie zapomóg w wysokości kilku milionów jenów, na zwiększenie tego typu hodowli w Mandżurii i na Półwyspie koreańskim. Jak jednak zauważa czasopismo, rozwiązanie to nie zaspokoi do końca problemu, gdyż corocznie Japonia importuje taką ilość wełny, jaką dostarcza 30 milionów owiec $^{29}$. Prasa podkreślała przy tym, że wpływ na handel wełną miał także konflikt na Dalekim Wschodzie. Świadczy o tym, zamieszczona w „Z Daleka i Bliska” krótka notatka takiej treści: „Do wojennych gospodarczych zarządzeń Japonii należy m.in. przymus używania do wyrobu przędzy wełnianej, tkanin wełnianych (a niebawem i bawełniane zapewne (pewnej

26 Inwazja gospodarcza Japonii na Bałkany, „Z Daleka i Bliska”, R. 6, nr 54-55, Lwów, czerwiec-wrzesień 1938, s. 211.

27 Japonia kupuje len wileński, „Z Daleka i Bliska”, R. 7, nr 59, Lwów, styczeń 1939, s. 28.

28 Rękawiczki dla Belgii, sukno dla Persji, lokomotywy dla Chin, „Z Daleka i Bliska”, R. 4, nr 29, Lwów, styczeń 1936, s. 26.

29 Japonia zwiększa hodowlę owiec, „Z Daleka i Bliska”, R. 4, nr 37, Lwów, listopad 1936, s. 267. 
ilości celulozy (od 10-30\%). Wyjątek stanowią wyroby przeznaczone na wywóz i cele wojskowe"30.

\section{Radiofonia japońska}

Japonia miała być także ojczyzną radiofonii. Na łamach czasopisma „Antena” wielokrotnie pojawiły się artykuły poświęcone tej tematyce. Możemy się z niej dowiedzieć, że radiofonia japońska - „Nippon Hoso Kyokai”, która powstała w 1925 roku, jest jedną z najpotężniejszych na świecie, a także odgrywa pierwszoplanową rolę w życiu kraju. W 1938 roku liczyła ona ponad 3,5 miliona słuchaczy i posiadała 43 stacje. Szczególnie na tym tle wyróżniał się sześciopiętrowy budynek radiostacji w Osace, będący jednym $z$ najnowocześniejszych $w$ tym regionie ${ }^{31}$.

Czasopismo podkreślało, że chociaż programy radiofonii są zbliżone do europejskich, to japońskie audycje znacznie więcej czasu antenowego poświęcają ćwiczeniom fizycznym i dydaktyce, a także ich programy są bardziej urozmaicone niż na Starym Kontynencie. Szczególnym zainteresowaniem cieszyły się wśród Japończyków audycje muzyczne, które zajmują ok. 60\% czasu antenowego. Wśród nich królowała zarówno muzyka japońska grana na tradycyjnych instrumentach takich jak: shamisen, koto, shakuhachi, jak i muzyka zachodnia, np. jazz, albo muzyka poważna europejska. Innymi cieszącymi się popularnością programami były: trwające sześć godzin dziennie programy dla dzieci, japońskie sztuki klasyczne, w tym teatr Noh, a także słuchowiska o tematyce historycznej ${ }^{32}$. Ponadto popularnością cieszyły się także audycje poświęcone nauce aż sześciu języków obcych: angielskiego, niemieckiego, francuskiego, chińskiego, mandżurskiego i portugalskiego ${ }^{33}$.

Polscy czytelnicy „Anteny” dowiadywali się także o tym, jak działa radio w Japonii. Na łamach prasy ukazał się m.in. wywiad $\mathrm{z}$ korespondentem prasy z Kojiro Kobune - dyrektorem i dyrygentem radiowej orkiestry

30 Celuloza w przemyśle włókienniczym w Japonii, „Z Daleka i Bliska”, R. 6, nr 51, Lwów, marzec 1938, s. 92.

31 R. Fajans, Radio w Japonii, „Antena”, R. 5, nr 44, 30 października, s. 7.

32 W. Burkath, Radjo w Krainie Kwitnącej Wiśni, „Antena”, R. 2, nr 43, 27 października 1935, s. 13; R. Fajans, Radio w Japonii, „Antena”, R. 5, nr 44, 30 października, s. 7; A. Wal, Muzyka i Radio w Japonii, „Antena”, R. 6, nr 28, 9 lipca 1939, s. 11.

33 Wojna Żółtych, „Antena”, R. 4, nr 37, 12 września, s. 8. 
symfonicznej w Tokio ${ }^{34}$. Samo radio, a także pierwsza japońska rozgłośnia radiowa, zyskała szybko bardzo dużą popularność w tym kraju. O ile w 1926 roku istniały tylko 3 małe stacje, każda o mocy $1 \mathrm{~kW}$, to zaledwie dekadę później, w 1937 - z 30 stacji 1/3 pracowała z mocą $10 \mathrm{~kW}$. Samych radioabonamentów w Kraju Wschodzącego Słońca było aż 1475 tysięcy ${ }^{35}$. Ponadto Japońskie Towarzystwo Radiowe miało rozpocząć przygotowania do transmisji radiowych z Olimpiady w 1940 roku $^{36}$.

„Antena” informowała również o tym, że już radiofonia japońska pracowała nad uruchomieniem telewizji, która w tym kraju cieszyła się dużym zainteresowaniem już w drugiej połowie lat 30. XX wieku. Prasa podkreślała, że Japońskie Towarzystwo Radiowe posiadało specjalne laboratorium, w którym pracowano nad stworzeniem telewizora, tak aby w czasie Olimpiady, która miała się odbyć w Tokio w 1940 roku, można było nadawać obrazy telewizyjne z rozgrywek na odległość $12 \mathrm{mil} \mathrm{od}$ stolicy. W tym też celu Japończycy także prowadzili prace nad użyciem fal krótkich poniżej $10 \mathrm{~cm}$, gdyż, jak stwierdzono, tego typu fale pomiędzy 10 a 5 cm korzystnie wpływają na wegetację ${ }^{37}$.

„Antena” wspomniała także o tym, że japońska radiofonia była również narzędziem propagandy na okupowanych przez nią terenach. Jedną z takich „uzależnionych” radiostacji był, uruchomiony przez Japończyków, Wielki Szanghaj. Nadawał on kontrolowane audycje artystyczne, dziecięce, poświęcone nauce języka japońskiego. Aby dotrzeć do większego grona osób, programy były nadawane w języku chińskim (w dialekcie pekińskim i szanghajskim $)^{38}$. Podobnie wyglądała sytuacja także w Korei, na Formozie i w Mandżurii, gdzie radiofonie również nadawały programy służące interesom Japoniii ${ }^{39}$. Tym działaniom przeciwstawiali się Chińczycy, którzy zaczęli nadawać własne programy. Jednak jak za-

34 A. Wal, Muzyka i Radio w Japonii, „Antena”, R. 6, nr 28, 9 lipiec 1939, s. 11.

35 Polska i Świat - Radiostacja Japońska, „Antena”, R. 4, nr 21, 23 maja 1937 r., s. 13.

36 Świat Radia - Japońskie przygotowania radiowe na Olimpiadę 1940 r., „Antena", R. 4, nr 22, 30 maja 1937 r., s. 13.

37 Świat Radia - Telewizja w Japonii, „Antena”, R. 4, nr 14, 4 kwietnia 1937 r., s. 11.

38 Świat Radia - Uruchomienie stacji Wielki Szanghaj, „Antena”, R. 5, nr 6, 6 lutego 1938 r., s. 15.

39 Wojna Żóltych, „Antena” R. 4., nr 37, 12 września, s. 8. 
uważa tytuł, większe sukcesy na tym polu odnosili wciąż Japończycy ${ }^{40}$. Innym „wojennym” zadaniem radia japońskiego było przekazywanie na bieżąco wydarzeń $\mathrm{z}$ frontu. Informowało ono poddanych cesarza Hirohito m.in. o szturmie na chińskie miasto Suzhou. W tym też celu wojsko wysłało na pierwszą linię ognia zarówno korespondenta wojennego, jak i radiotechnika ${ }^{41}$.

\section{Podsumowanie}

Problematyka związana z Japonią wielokrotnie pojawiała się w czasopismach o różnej tematyce: zarówno naukowej i popularnonaukowej, krajoznawczej, jak i informacyjnej. Kraj Kwitnącej Wiśni jest w nich przedstawiany w różny sposób, jako: nowoczesne państwo, baśniowa orientalna kraina, kraj pogrążony w kryzysie, albo burzyciel pokoju na Dalekim Wschodzie. Nierzadko Japonia ukazywana jest również jako kraj kontrastu, gdzie nowoczesność wciąż styka się z tradycją.

Warto podkreślić, że zazwyczaj to właśnie prasa kształtowała wiedzę przeciętnego obywatela II Rzeczpospolitej o Kraju Wschodzącego Słońca, którego wiedza była zazwyczaj niewielka i powierzchowna. Wyjątek stanowili tutaj orientaliści oraz osoby, które bezpośrednio nawiązywali kontakty z mieszkańcami Kraju Kwitnącej Wiśni. Z drugiej strony Polacy byli zainteresowani japońską tematyką. Można wymienić tutaj kilka przyczyn: fascynacja intrygującą i bogatą kulturą, sentyment do Japonii (wojna rosyjsko-japońska; pomoc Japończyków polskim dzieciom), ale także śledzenie napiętej sytuacji politycznej na Dalekim Wschodzie (istnienie kilkusetnej Polonii w okupowanej przez Japonię Mandżurii).

Prasa zaznaczała, że Japonia jest jednym $\mathrm{z}$ najbardziej rozwiniętych państw na świecie, a także podkreślała jej ważną rolę na arenie międzynarodowej. Z drugiej strony wielokrotnie wspominała, że to samo państwo jest także odpowiedzialne za konflikt na Dalekim Wschodzie, a w przyszłości może zagrozić suwerenności innych państw w tym regionie.

Japonia jawi się także jako państwo nowoczesne $\mathrm{z}$ dobrze rozwiniętą technologią, m.in. rozbudowanym systemem radiofonii, ale także jako kraj rolniczy, który musi borykać się z wieloma trudnościami. Do naj-

40 Tamże.

41 Świat Radia-Bezpośredni reportaż z wojny japońsko-chińskiej, „Antena”, R. 5, nr 23, 5 czerwca 1938 r., s. 13. 
ważniejszych problemów Japonii „Wschód”, „Z Daleka i Bliska” oraz „Antena”, zalicza: przeludnienie, ubogość w zasoby naturalne oraz złoża, a także często nawiedzające wyspy kataklizmy naturalne, a szczególnie trzęsienia ziemi.

Z prasy dowiadujemy się również, że Japonia odgrywa ważną rolę $\mathrm{w}$ handlu międzynarodowym. Wynika to $\mathrm{z}$ tego, że jest ona głównym producentem i eksporterem jedwabiu oraz ryżu. Sama przy tym musi jednak sprowadzać liczne surowce, $\mathrm{w}$ tym przede wszystkim wełnę oraz dobra luksusowe, nie tylko z Azji, ale także Europy, w tym również z Polski. 